\title{
Knowledge and Awareness of Biomedical Waste Management among Final Year MBBS Students in a Medical College and Teaching Hospital in Hyderabad, Telangana
}

\author{
R. Shyamala ${ }^{1}$, N. Shreya ${ }^{3}$ and P. Palavardhan ${ }^{2} *$ \\ ${ }^{1}$ Department of Microbiology, ${ }^{2}$ Department of Community Medicine, ${ }^{3}$ Malla Reddy Medical \\ College for Women, Hyderabad, Telangana, India \\ *Corresponding author
}

\author{
A B S T R A C T
}

\section{Ke y w o r d s \\ Bio medical waste, Infectious medical waste, Waste management, Waste disposal}

\section{Article Info}

Accepted:

23 April 2020

Available Online:

10 May 2020
Biomedical Waste means any waste which is generated during the diagnosis, treatment or immunization of human beings or animals or in research activities pertaining thereto or in the production or testing of biologicals. Teaching institutes play a critical role in health care setup, as it is here that the future health care professionals are trained. The aims and objectives of this study are a) To evaluate the knowledge of final year MBBS students about biomedical waste management b)To evaluate the level of awareness of final year MBBS students towards biomedical waste management. Institutional Ethical Committee Clearance was obtained from Institutional Ethics Committee. This study was done in Malla Reddy Medical College for Women (MRMCW) Hyderabad, Telangana State. The questionnaire was distributed to 100 final year MBBS students of MRMCW in Hyderabad Telangana state and they were given 30 minutes for completing the questionnaire and then later the questionnaire was collected from the students. A cross sectional questionnaire was designed, the questionnaire consisted of 20 questions regarding the knowledge and awareness of students towards Biomedical Waste Management. The results were analysed and we had conducted one workshop to bridge their gaps. We are planning few more workshops in future about biomedical waste management.

\section{Introduction}

Biomedical Waste means any waste which is generated during the diagnosis, treatment or immunization of human beings or animals or in research activities pertaining thereto or in the production or testing of biological (1).

The waste produced in the course of the health care activities carries a higher potential for infection and injury than any other type of waste (1). Inadequate and inappropriate handling of health care waste may have serious public health consequences and a significant impact on the environment (1). All individuals exposed to such hazardous health care waste or those who either handle such waste are exposed to it as a consequence of careless management. "Handling" in relation to biomedical waste management includes the 
generation, sorting, segregation, collection, use, storage, packaging, loading, transportation, unloading, processing, treatment, destruction, conversion or offering for sale, transfer, disposal of such waste (2) "Management" includes all steps required to ensure that biomedical waste is managed in such a manner as to protect health and environment against any adverse effects due to handling of such waste (2).

Expansion of health care facilities with the advancement of modern technologies as well as recent trend of using disposables has led to a high burden of health care related wastes (3).

Appropriate knowledge of management of health care waste is thus a crucial component of environmental health protection and it should become an integral feature of health care services. Process of managing the medical waste includes segregation, separation, packaging and labelling, common storage, transportation, treatment (4).

Among $75-90 \%$ of the waste produced by hospitals is non hazardous and it is estimated that remaining $10-25 \%$ carry a high potential for infection and injury (5).

Teaching institutes play a critical role in health care setup, as it is here that the future health care professionals are trained.

\section{According to World Health Organization the Types of waste are as follows}

Waste and by-products cover a diverse range of materials, as the following list illustrates:

Infectious waste: waste contaminated with blood and other bodily fluids (e.g. from discarded diagnostic samples), cultures and stocks of infectious agents from laboratory work (e.g. waste from autopsies and infected animals from laboratories), or waste from patients with infections (e.g. swabs, bandages and disposable medical devices);

Pathological waste: human tissues, organs or fluids, body parts and contaminated animal carcasses

Sharps waste: syringes, needles, disposable scalpels and blades, etc.

Chemical waste: for example solvents and reagents used for laboratory preparations, disinfectants, sterilants and heavy metals contained in medical devices (e.g. mercury in broken thermometers) and batteries;

Radioactive waste: such as products contaminated by radionuclides including radioactive diagnostic material or radiotherapeutic materials; and

Non-hazardous or general waste: waste that does not pose any particular biological, chemical, radioactive or physical hazard.

Pharmaceutical waste: expired, unused and contaminated drugs and vaccines;

Cytotoxic waste: waste containing substances with genotoxic properties (i.e. highly hazardous substances that are, mutagenic, teratogenic or carcinogenic), such as cytotoxic drugs used in cancer treatment and their metabolites (6).

\section{Materials and Methods}

To evaluate the knowledge of final year MBBS students about biomedical waste management

To evaluate the level of awareness of final year MBBS students towards biomedical waste management.

Institutional Ethical Committee Clearance was obtained from Institutional Ethics Committee. This study was done in Malla Reddy Medical College for Women Hyderabad, Telangana State.

The questionnaire was distributed to 100 final year MBBS students of Malla Reddy Medical 
College for Women in Hyderabad Telangana state and they were given 30 minutes for completing the questionnaire and then later the questionnaire was collected from the students .A cross sectional questionnaire was designed, the questionnaire consisted of 20 questions regarding the knowledge and awareness of students towards Biomedical Waste Management.

\section{Questionnaire}

Section-1, Knowledge of biomedical waste generation, hazards and legislature

1. Are there any guidelines laid down by Government of India regarding Biomedical waste management
a)Yes
b)No
c) don't know

2. Are you aware regarding the regulations and legislature of biomedical waste management in India
a) Yes
b) No
c)not sure

3. Do you think it is important to know about Biomedical waste generation, hazards and management
a) Yes.
b) No.
c) don't know

4. Do you know the biohazard symbol
a) Yes.
b) No.
c) not sure

5. According to biomedical waste management and handling rules, untreated waste shouldn't be stored beyond 48hrs?
a) Yes
b) $\mathrm{No}$
c) Not sure

\section{Section-2: Level of awareness on biomedical waste management practice}

6. Do you know about colour code segregation of biomedical waste
a) Yes
b) No
c) Not sure

7. Does your hospital follow correct biomedical waste practice
a) Yes
b) No
c) Not sure

8. Do you think segregation of biomedical waste should be done at the source of waste products
a) Yes
b) No
c) not sure

9. Is needle stick injury a concern
a) Yes
b) No
c) not sure

10. Are you aware of consequences of needle stick injury
a) Yes
b) $\mathrm{No}$
c) Not sure

11. Needles go in which colour bin
a) Red
b) yellow
c) blue
d) white/translucent

12. Used gloves go in which colour bin
a)Red
b) yellow
c) blue
d) white/translucent

13. Placenta go in which colour bin
a. Red.
b) yellow.
c) blue
d) white/translucent

14. Metallic body implants go in which colour bin
a) Red.
b) yellow.
c) blue
d) white/translucent

15. Proper and safe management of biomedical waste is not an issue
a) Yes
b) No
c) Not sure

16. Do you think medical staff should be given knowledge and training regarding safe biomedical waste management
a) Yes.
b) No
c) Not sure

17. Would you like to attend programmes that would increase your knowledge about biomedical waste management 

a) Yes
b) No
c) Not sure

18. Do you think biomedical waste management is a team work and not a single group of people are responsible for it
a) Yes
b) No
c) Not sure

19. Do you think biomedical waste management should be checked before setting up blood camps, vaccination camps or other health activities
a) Yes
b) No
c) Not sure

20. During your health care practice do you think you will be practicing Biomedical waste management rules
a) Yes
b) No
c) Not sure

The above Questionairre was given to the final year MBBS Students.

\section{Results and Discussion}

The data was collected from the Questionairre distributed to students and the graphs were made for all the 20 questions.

The results were as follows:-

The results were tabulated as number of students marked yes, number of students marked no, number of students marked not sure.

For Question number 11 to 14 , it is the color of bin red or yellow or blue or white is the choice provided.

The following are the graphs for different questions in Questionairre given to the final year MBBS Students.

Table.1 Questionnairre results

\begin{tabular}{|c|c|c|c|c|}
\hline S.No. & Question & $\begin{array}{c}\text { Yes } \\
\text { No of students } \\
\text { marked yes }\end{array}$ & $\begin{array}{c}\text { No } \\
\text { No of students } \\
\text { marked No }\end{array}$ & $\begin{array}{c}\text { Not Sure } \\
\text { No of students } \\
\text { marked Not sure }\end{array}$ \\
\hline 1. & $\begin{array}{l}\text { Are there any guidelines } \\
\text { laid down by Government } \\
\text { of India regarding } \\
\text { Biomedical waste } \\
\text { management }\end{array}$ & 90 & 0 & 10 \\
\hline 2. & $\begin{array}{l}\text { Are you aware regarding } \\
\text { the regulations and } \\
\text { legislature of biomedical } \\
\text { waste management in } \\
\text { India }\end{array}$ & 64 & 10 & 26 \\
\hline 3. & $\begin{array}{l}\text { Do you think it is } \\
\text { important to know about } \\
\text { Biomedical waste } \\
\text { generation, hazards and } \\
\text { management }\end{array}$ & 98 & 0 & 2 \\
\hline 4. & $\begin{array}{l}\text { Do you know the } \\
\text { biohazard symbol. }\end{array}$ & 89 & 6 & 5 \\
\hline 5. & According to biomedical & 45 & 36 & 19 \\
\hline
\end{tabular}




\begin{tabular}{|c|c|c|c|c|c|}
\hline & $\begin{array}{l}\text { waste management and } \\
\text { handling rules, untreated } \\
\text { waste shouldn't be stored } \\
\text { beyond } 48 \mathrm{hrs} \text { ? }\end{array}$ & & & & \\
\hline 6. & $\begin{array}{l}\text { Do you know about colour } \\
\text { code segregation of } \\
\text { biomedical waste }\end{array}$ & \multicolumn{2}{|r|}{83} & 2 & 15 \\
\hline 7. & $\begin{array}{l}\text { Does your hospital follow } \\
\text { correct biomedical waste } \\
\text { practice }\end{array}$ & \multicolumn{2}{|r|}{60} & 15 & 25 \\
\hline 8. & $\begin{array}{l}\text { Do you think segregation } \\
\text { of biomedical waste } \\
\text { should be done at the } \\
\text { source of waste products }\end{array}$ & \multicolumn{2}{|r|}{84} & 6 & 10 \\
\hline 9. & $\begin{array}{l}\text { Is needle stick injury a } \\
\text { concern }\end{array}$ & \multicolumn{2}{|r|}{93} & 1 & 6 \\
\hline 10 . & $\begin{array}{l}\text { Are you aware of } \\
\text { consequences of needle } \\
\text { stick injury }\end{array}$ & \multicolumn{2}{|r|}{84} & 5 & 11 \\
\hline \multirow[t]{2}{*}{11} & \multirow[t]{2}{*}{$\begin{array}{l}\text { Needles go in which } \\
\text { colour bin }\end{array}$} & $\begin{array}{l}\text { Red } \\
\text { Bin }\end{array}$ & yellow & \multirow[t]{2}{*}{$\begin{array}{c}\text { Blue } \\
6\end{array}$} & \multirow[t]{2}{*}{$\begin{array}{l}\text { White } \\
81\end{array}$} \\
\hline & & 10 & 3 & & \\
\hline \multirow[t]{2}{*}{12} & \multirow[t]{2}{*}{$\begin{array}{l}\text { Used gloves go in which } \\
\text { colour bin }\end{array}$} & \begin{tabular}{c|} 
red \\
39 \\
\end{tabular} & $\begin{array}{c}\text { yellow } \\
24\end{array}$ & Blue & White \\
\hline & & & & 27 & 10 \\
\hline \multirow[t]{2}{*}{13} & \multirow[t]{2}{*}{$\begin{array}{l}\text { Placenta go in which } \\
\text { colour bin }\end{array}$} & red & yellow & blue & white \\
\hline & & 34 & 59 & 5 & 2 \\
\hline \multirow[t]{3}{*}{14} & \multirow[t]{2}{*}{$\begin{array}{l}\text { Metallic body implants go } \\
\text { in which colour bin }\end{array}$} & red & yellow & Blue & White \\
\hline & & 15 & 9 & 50 & 26 \\
\hline & & \multicolumn{2}{|r|}{ Yes } & No & Not Sure \\
\hline 15 & $\begin{array}{l}\text { Proper and safe } \\
\text { management of } \\
\text { biomedical waste is not an } \\
\text { issue }\end{array}$ & \multicolumn{2}{|r|}{19} & 75 & 6 \\
\hline 16 & $\begin{array}{l}\text { Do you think medical staff } \\
\text { should be given } \\
\text { knowledge and training } \\
\text { regarding safe biomedical } \\
\text { waste management }\end{array}$ & \multicolumn{2}{|r|}{99} & 0 & 1 \\
\hline
\end{tabular}




\begin{tabular}{|l|l|l|l|l|}
\hline $\mathbf{1 7}$ & $\begin{array}{l}\text { Would you like to attend } \\
\text { programmes that would } \\
\text { increase your knowledge } \\
\text { about biomedical waste } \\
\text { management }\end{array}$ & 82 & 13 & 5 \\
\hline $\mathbf{1 8}$ & $\begin{array}{l}\text { Do you think biomedical } \\
\text { waste management is a } \\
\text { team work and not a } \\
\text { single group of people are } \\
\text { responsible for it }\end{array}$ & 98 & 1 & 1 \\
\hline $\mathbf{1 9}$ & $\begin{array}{l}\text { Do you think biomedical } \\
\text { waste management should } \\
\text { be checked before setting } \\
\text { up blood camps, } \\
\text { vaccination camps or } \\
\text { other health activities }\end{array}$ & 91 & 5 & 4 \\
\hline $\mathbf{2 0}$ & $\begin{array}{l}\text { During your health care } \\
\text { practice do you think you } \\
\text { will be practicing } \\
\text { Biomedical waste } \\
\text { management }\end{array}$ & & & \\
\hline
\end{tabular}

Graph.1 Pertaining to $1^{\text {st }}$ question and graph 2 pertaining to $2^{\text {nd }}$ question and so on till 20 questions.

Graph.1

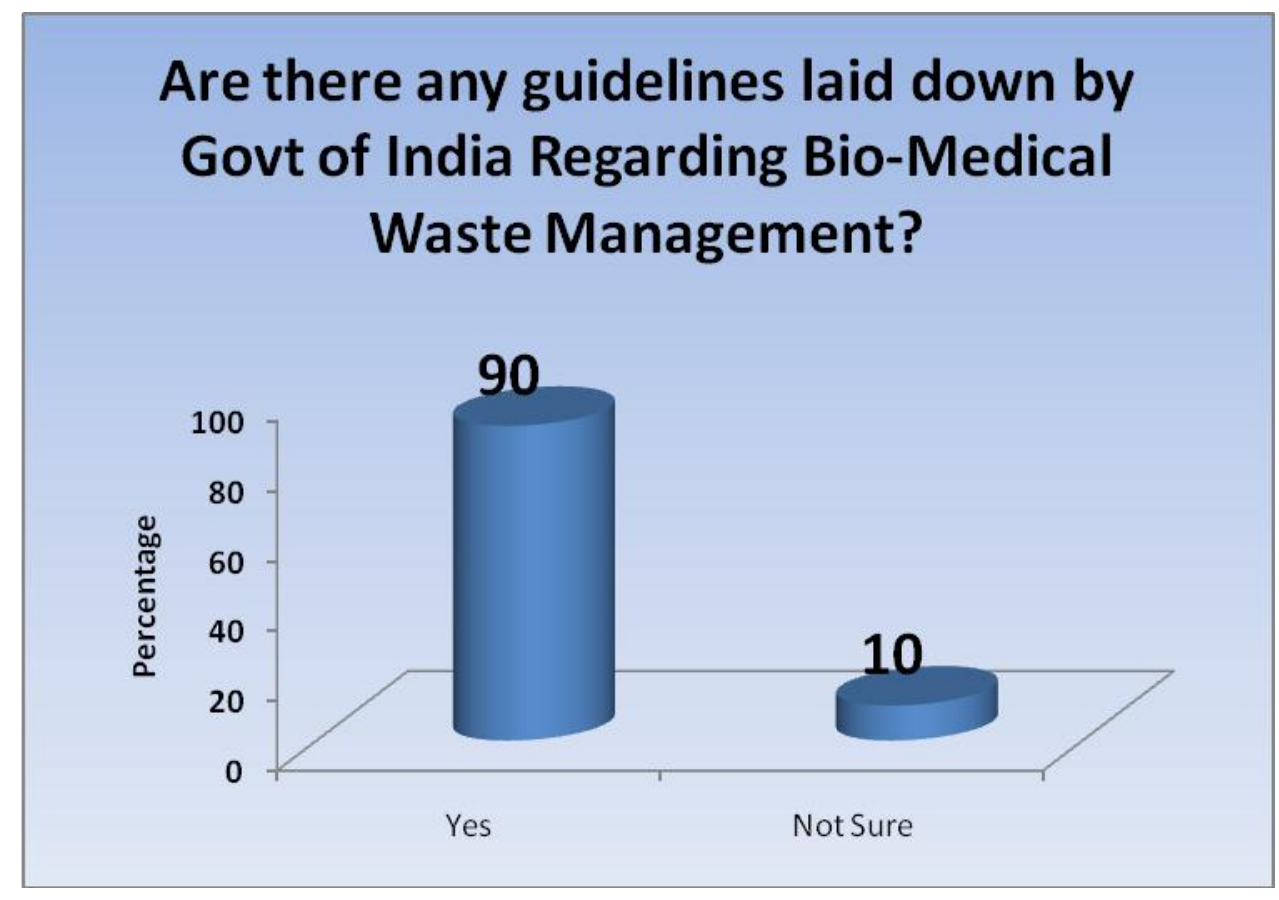


Graph.2

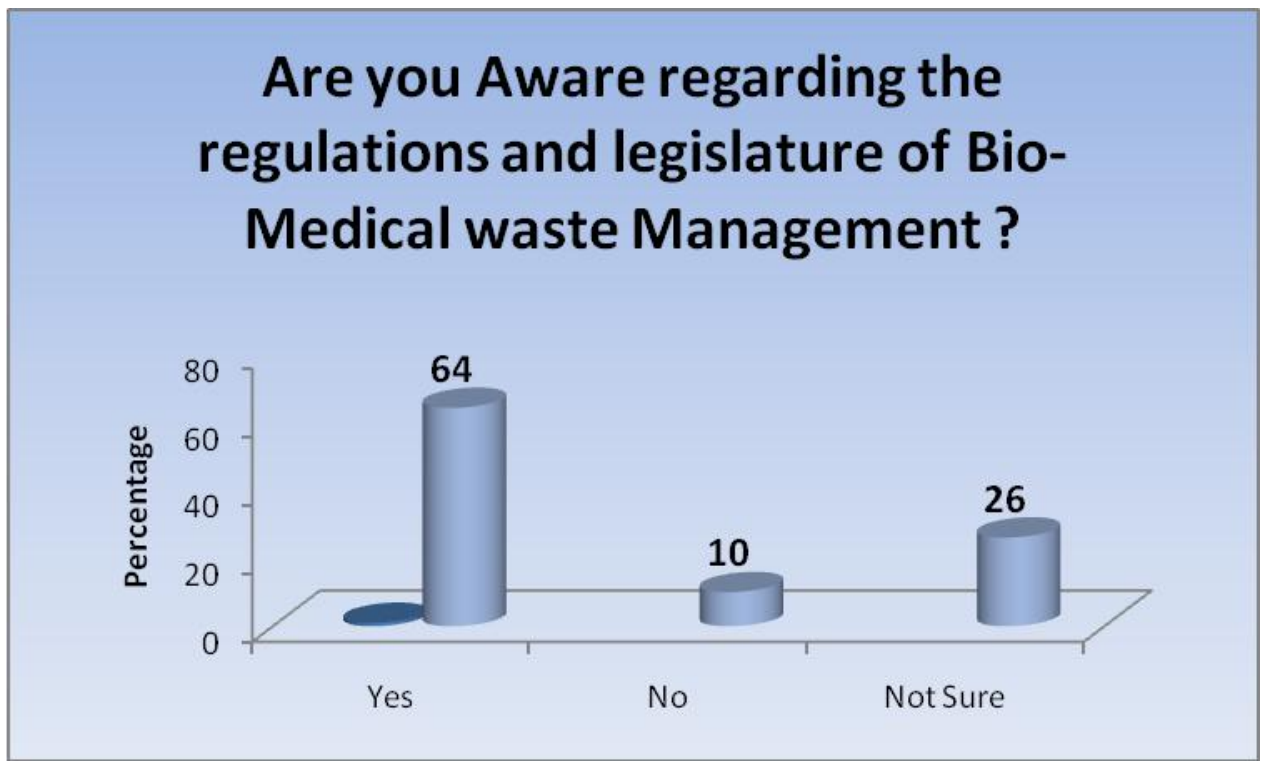

Graph.3

Do you think it is important to know about Biomedical waste generation, hazards and management?

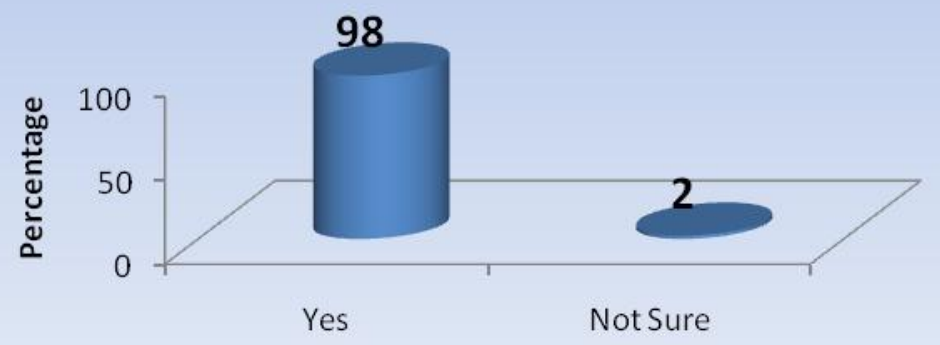


Graph.4



Graph.5

\section{According to biomedical waste management and handling rules, waste should not be stored beyond.}

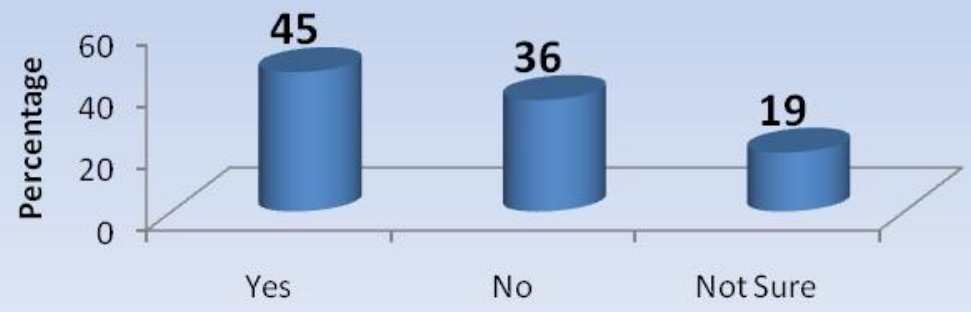


Graph.6

Do you know about the colour code segregation of biomedical waste?

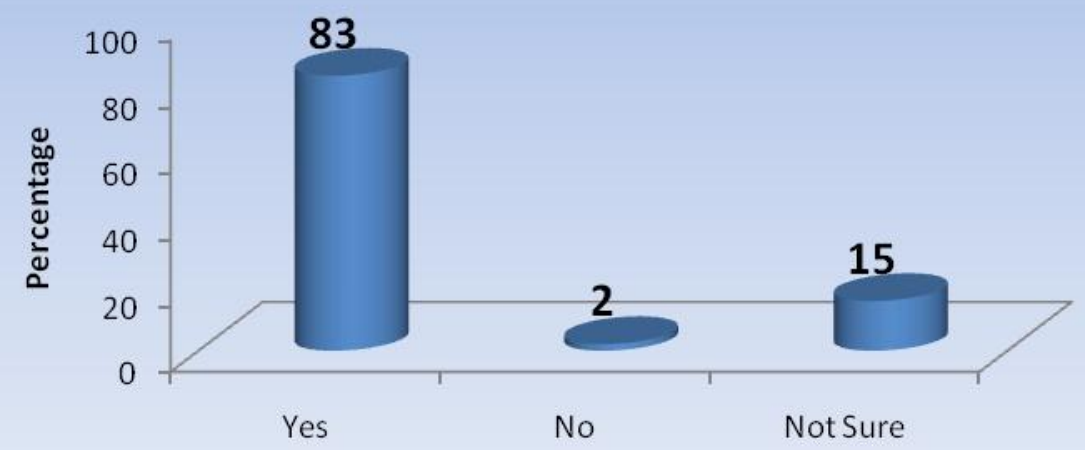

Graph.7

\section{Does your hospital follow correct biomedical waste practice?}

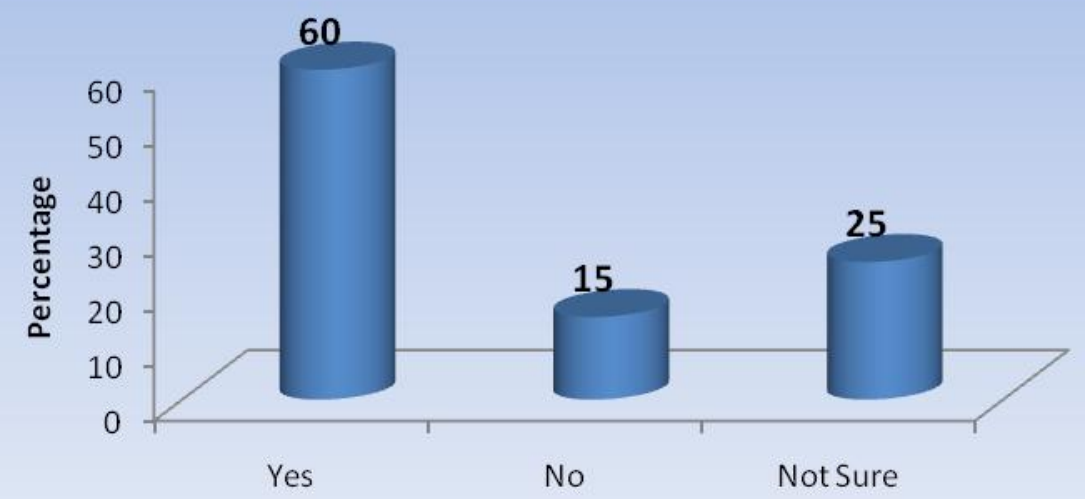




\section{Graph.8}

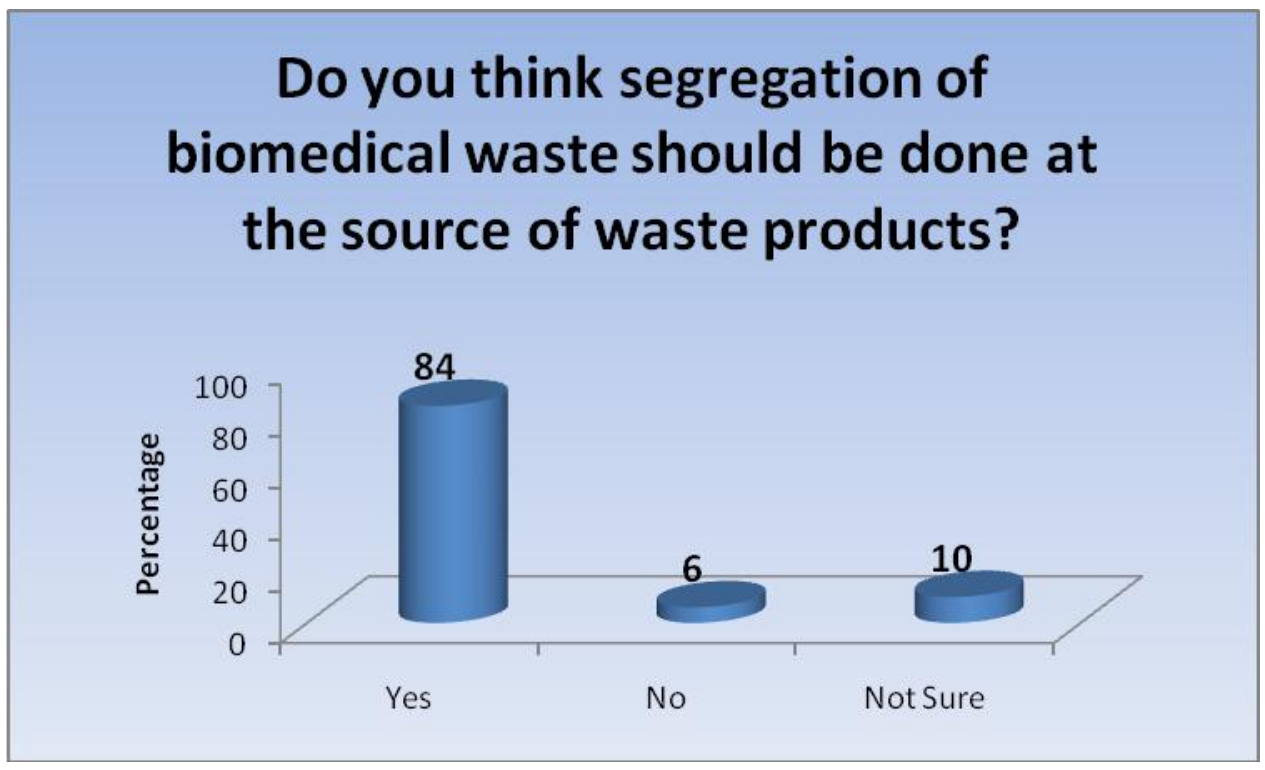

Graph.9

\section{Is needle stick injury a concern ?}

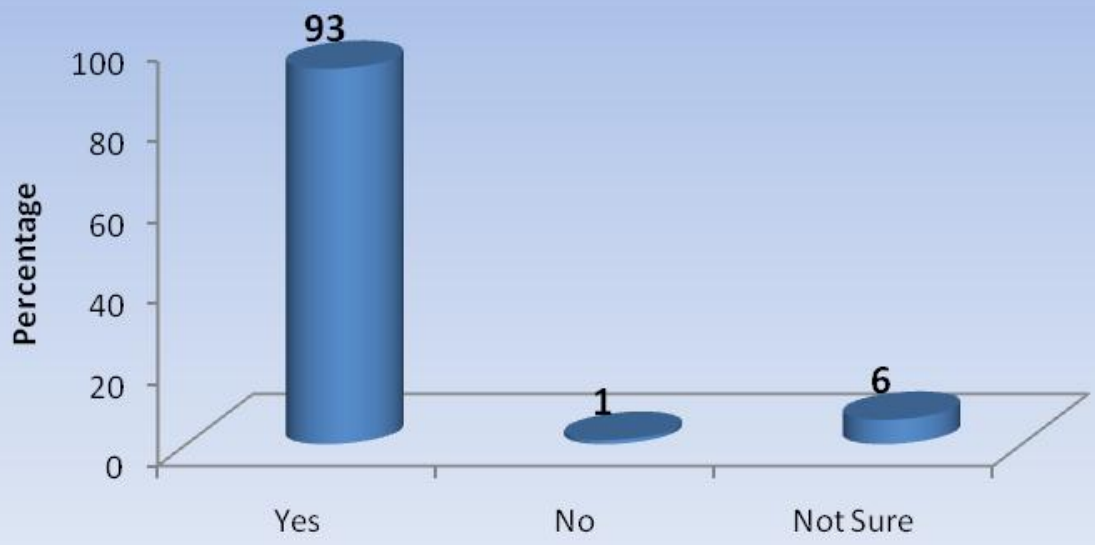


Graph.10

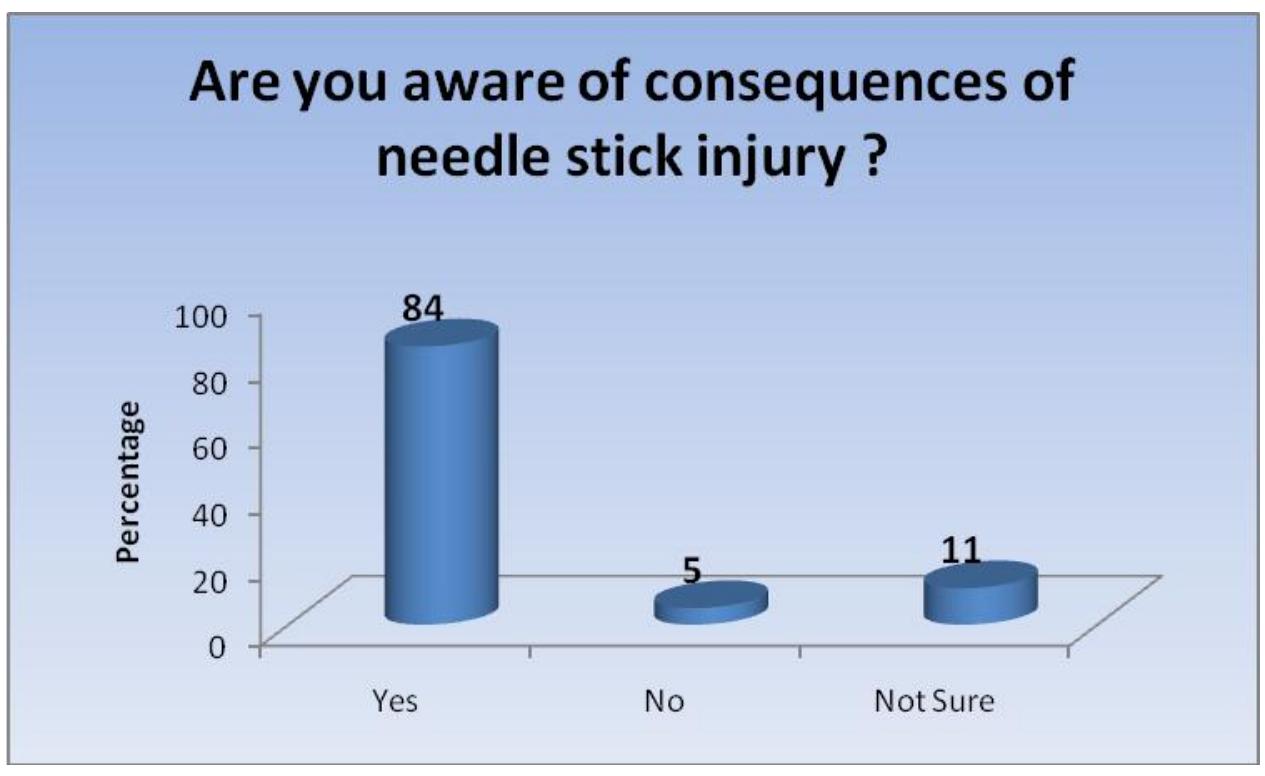

Graph.11

\section{Needles go in which colour bin?}

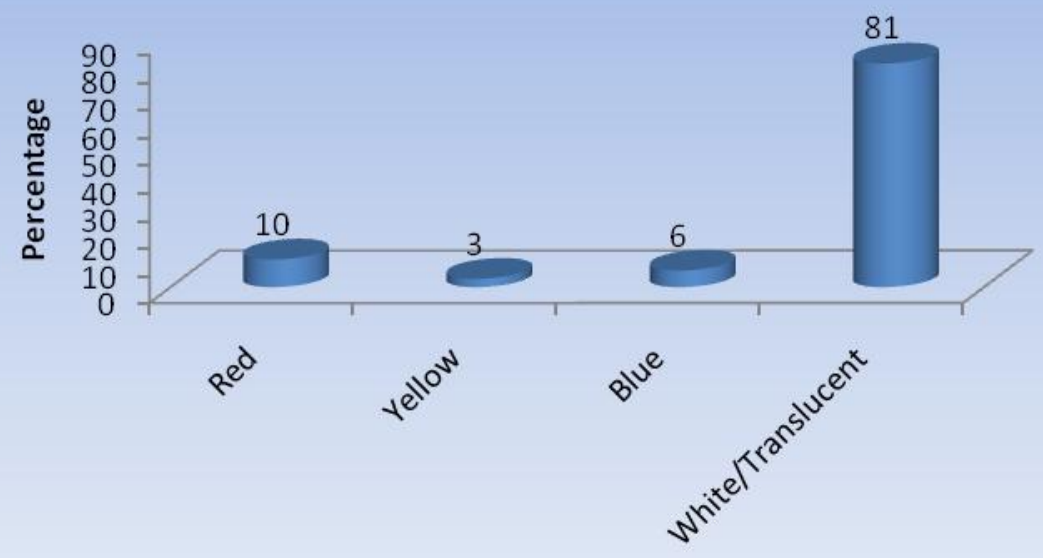




\section{Graph.12}

\section{Used gloves go in which colour bin ?}

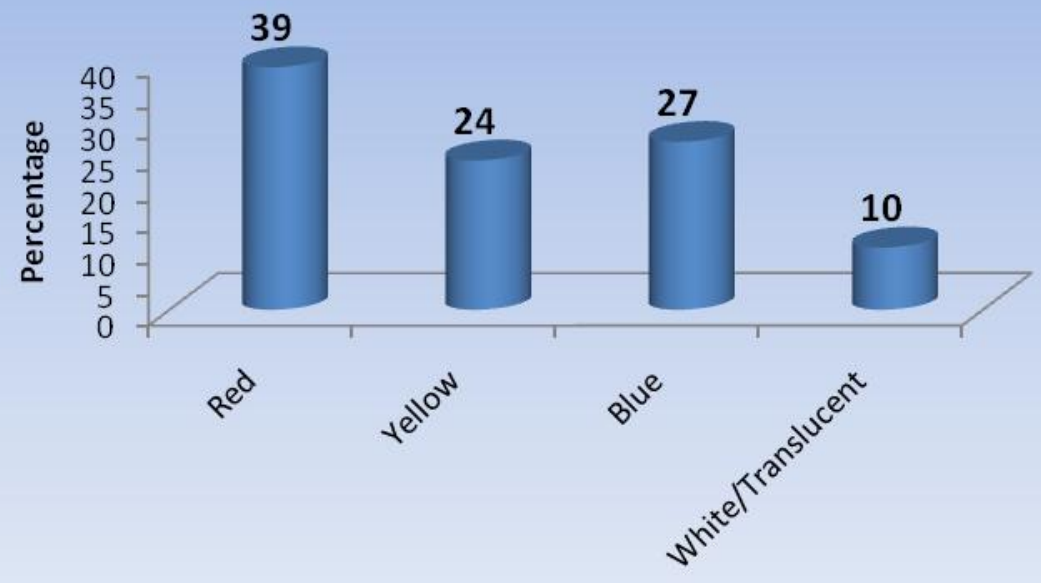

Graph.13

\section{Placenta go in which colour bin ?}

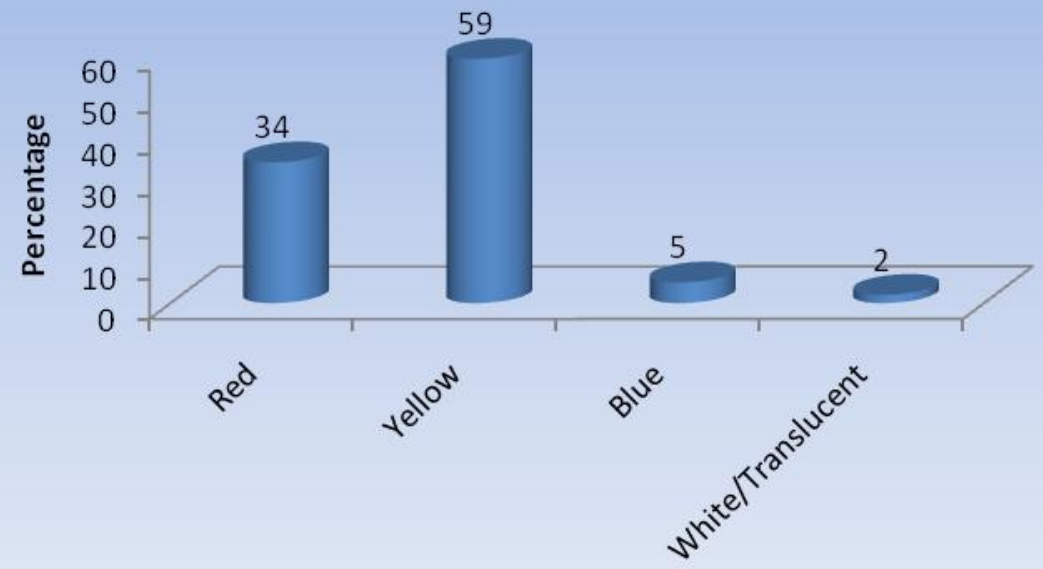


Graph.14

\section{Metallic body Implants go in Which colour bin?}

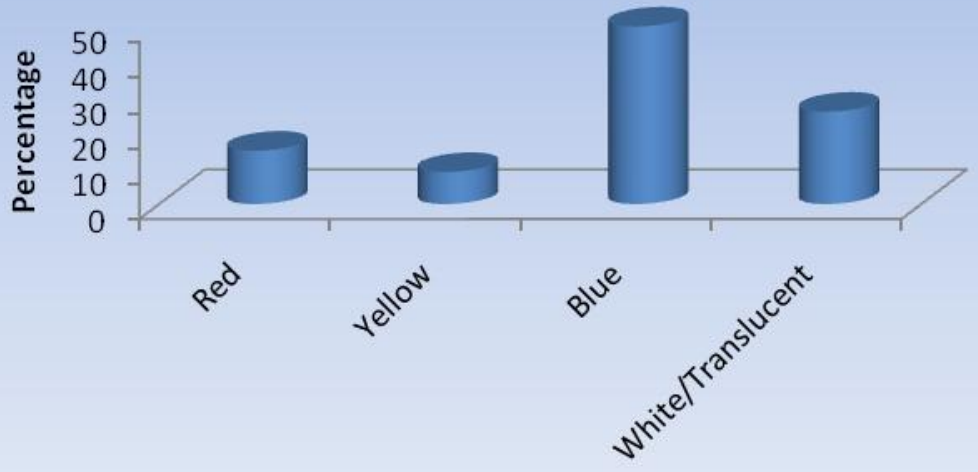

Graph.15

\section{Proper and safe management of biomedical waste is not an issue}

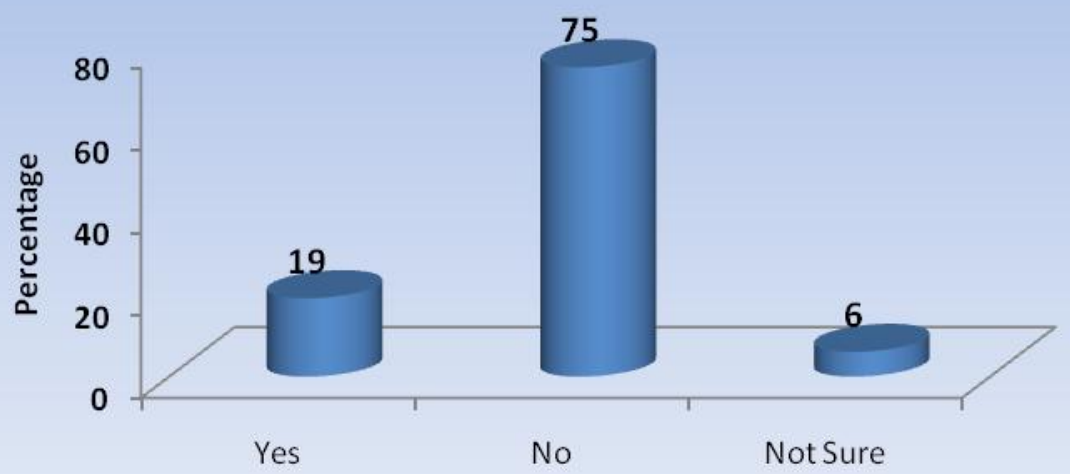


Graph.16

Do you think medical staff should be given knowledge and training regarding safe biomedicalwaste management?

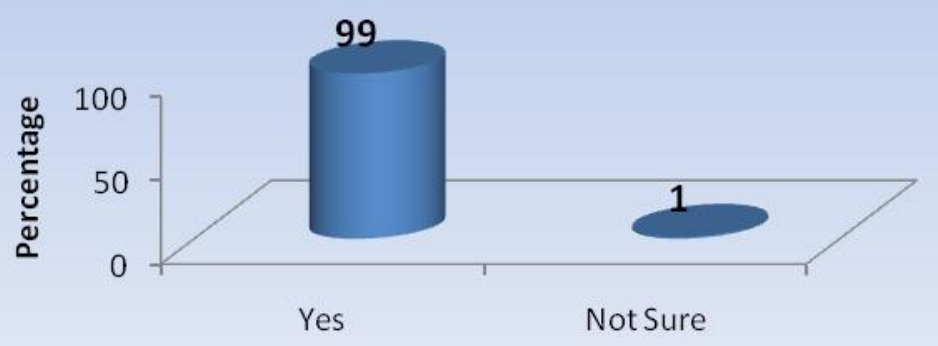

Graph.17

Would you like to attend programmes that would increase your knowledge about biomedical waste management

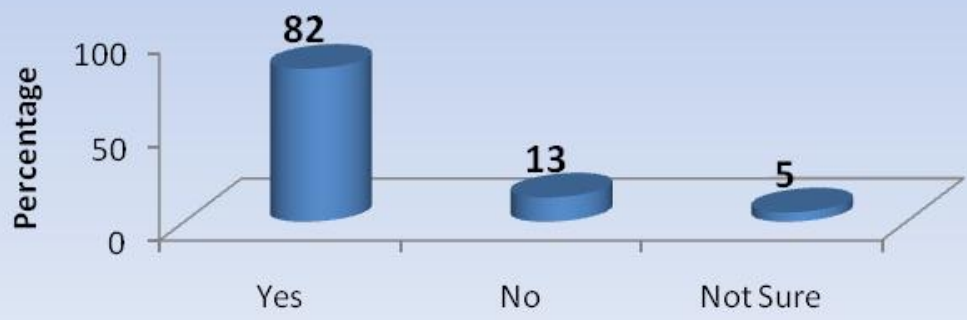


Graph.18

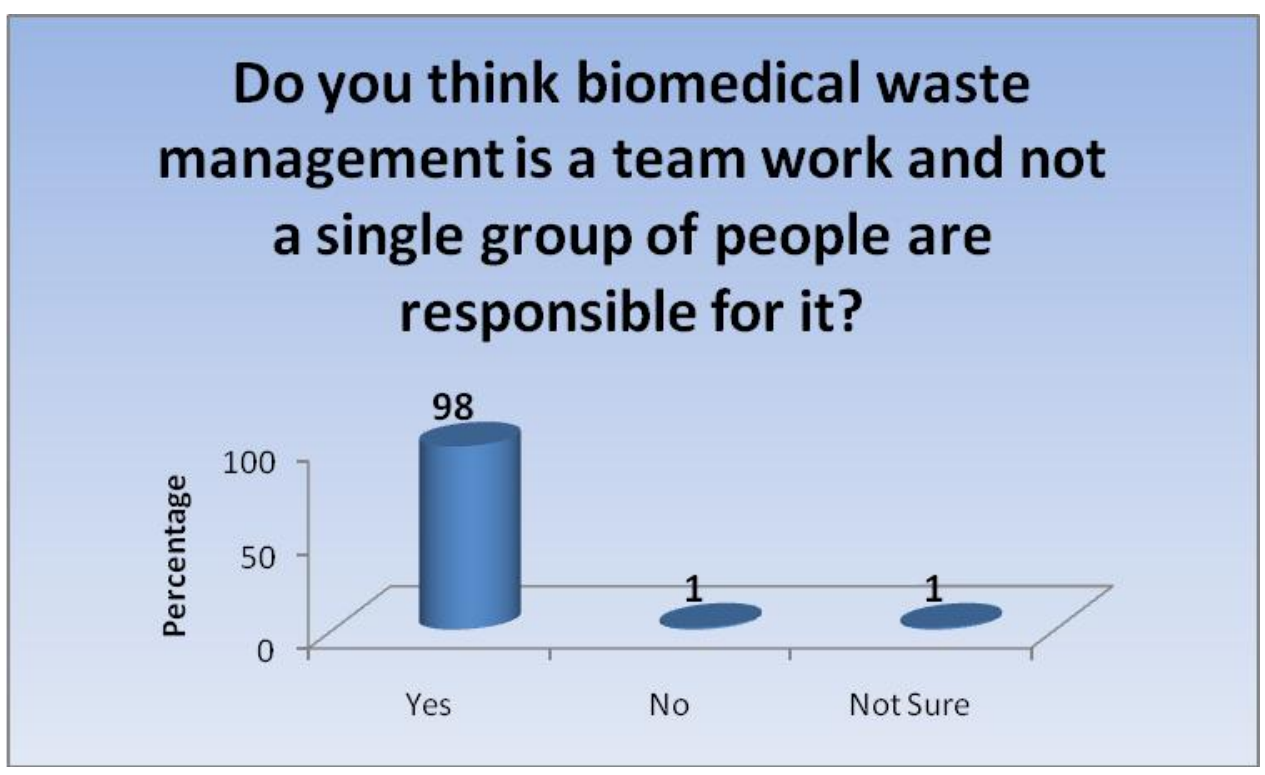

Graph.19

Do you think biomedical waste management should be checked before setting up blood camps, vaccination camps or other...

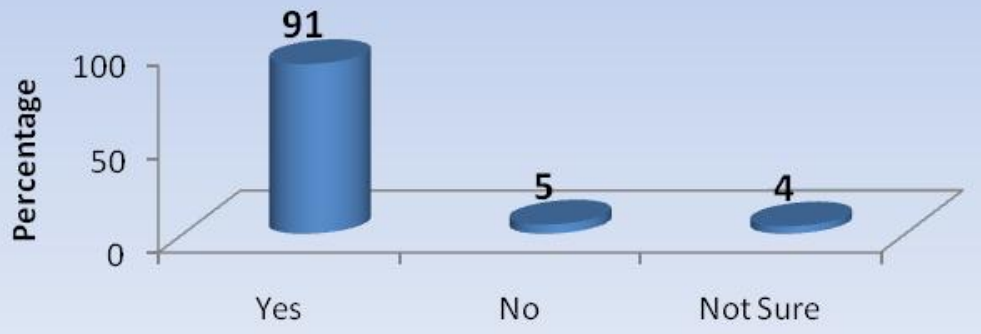


Graph.20

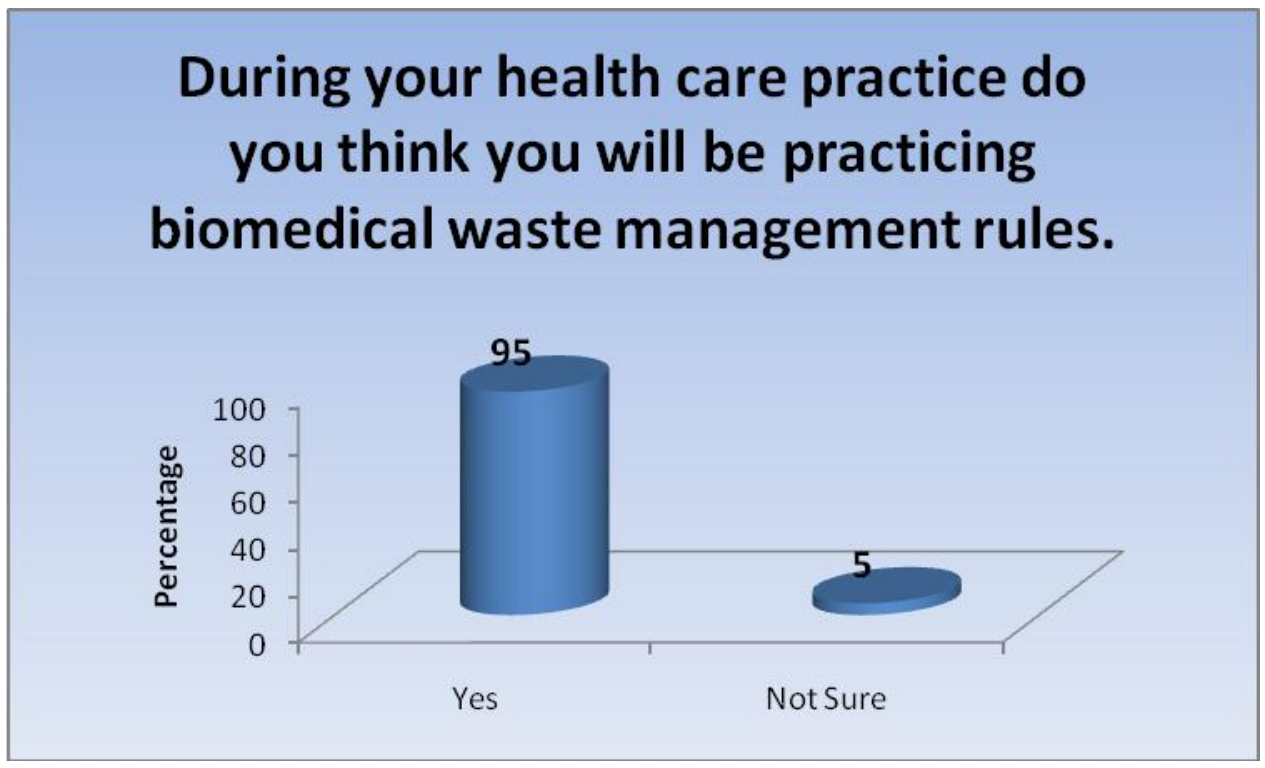

Lalita et al., (7). in this study concluded that majority of the respondents have unsatisfactory knowledge attitude and inadequate practices related to waste management.

The study was undertaken to know the knowledge and awareness of final year MBBS students about Biomedical Waste management. The study was to know their knowledge and awareness about proper disposal of biomedical waste and management. They are the future Health Care professionals.

The gaps in their knowledge were identified and a workshop was conducted after the study.

The present are planning for few more workshops for the final year MBBS students for the topic Biomedical Waste Management.

In conclusion, the results of the present study give an indication on the level of knowledge, awareness and attitude of final year MBBS students about biomedical waste management. A workshop was conducted to bridge the gaps and we have planned in the near future few more workshops for their better understanding of Biomedical Waste Management.

\section{References}

1. K. Park. Park's Textbook of Preventive and Social Medicine, $25^{\text {th }}$ edition, Bhanot publishers.

2. Government of India, Ministry of environment, Forest and Climate Change. Biomedical waste management rules. Gazette of India, part -2, section 3, sub section (I).

3. Dr Padmaja Kanchi. Knowledge, attitude, practice regarding hospitals waste management among interns and nurses in tertiary care hospitals of Navi Mumbai. ISSN 2320-6691. Scholars Journal of Applied Medical Sciences, 2017, Scholars Academic and Scientific publisher.

4. SuthaIrin A. An analytical study on medical waste management in selected hospitals located in Chennai city. Volume-1, issue -1, 2018,Journal of environmental waste management and recycling. 
5. AasthaPandey, CharanKaurDardi. Kap study on biomedical waste management among interns in a tertiary care hospital in Maharashtra. ISSN 2394-6032, Voluem-4, No-11, 2017 International Journal of community medicine and public health.

6. https://www.who.int/news-room/factsheets/detail/health-care-waste
7. LalitaArora, SunitaAgarwal. Knowledge, attitude and practices regarding waste management in selected hospital students of university of Rajasthan, Jaipur. International $\mathbf{J}$ of Chemical, Environmental and Pharmaceutical Research 2011; 2: 4043.

\section{How to cite this article:}

Shyamala, R., N. Shreya and Palavardhan, P. 2020. Knowledge and Awareness of Biomedical Waste Management among Final Year MBBS Students in a Medical College and Teaching Hospital in Hyderabad, Telangana. Int.J.Curr.Microbiol.App.Sci. 9(05): 2830-2846. doi: https://doi.org/10.20546/ijcmas.2020.905.325 